\title{
Lichen community diversity on a remnant forest in south of Chaco region (Cordoba, Argentina)
}

\author{
Diversidad de la comunidad liquénica en un bosque remanente del sur de la región chaqueña \\ (Córdoba, Argentina)
}

\author{
Cecilia Estrabou ${ }^{\mathrm{a}, \mathrm{b} *}$, Carolina Quiroga a , Juan Manuel Rodríguez a,b \\ *Corresponding author: ${ }^{\text {a }}$ Universidad Nacional de Córdoba, Facultad de Ciencias Exactas, Físicas y Naturales, \\ Centro de Ecología y Recursos Naturales Renovables. Av. Vélez Sarsfield 1604, Córdoba, Argentina, cecilia.estrabou@gmail.com \\ ${ }^{\mathrm{b}}$ CONICET - UNC, Instituto de Investigaciones Biológicas y Tecnológicas, Córdoba, Argentina.
}

\begin{abstract}
SUMMARY
The lichen community diversity in patches of Chaco forest -NE of Cordoba Province, Argentina was analyzed. Fifteen forest patches embedded in farmland areas were sampled. Size of the patch and exposure to the crops were registered. In each patch, ten trees (sample units) with epiphytic lichens were sampled. The cover for epiphytic lichen species and the number of species present were recorded. Shannon-Wiener diversity index was calculated for each patch and multivariate analyses (DCA and Indicator Species Analyses) were applied in order to study the composition of the community. The sample patches in the DCA were associated with patch exposition. Four quantitative variables (patch size, relative cover of Physciaceae, Parmeliaceae and Collemataceae; the most representative families) were related with the first two axes of DCA using correlations coefficients. Twenty one species in patches were identified. A multivariate analysis of sample units showed preferences of some species to exposure of patches to the crops. The data indicated that there would be a degradation marked by the impact of the edges on the remaining forests. There is a trend towards more homogeneous communities, formed by species resistant to these boundary conditions and possessing high coverage.
\end{abstract}

Key words: agriculture, Chaco, epiphytes, patches, community structure.

\section{RESUMEN}

Se analizó la diversidad de la comunidad liquénica del bosque chaqueño en el NE de la provincia de Córdoba, Argentina. Se registraron quince parches de bosque inmersos en áreas de cultivo, su exposición a los cultivos y el tamaño de los parches. En cada parche se muestrearon los líquenes epífitos de diez árboles (unidades muestrales). Se registró la cobertura y el número de especies presentes. Se calculó el índice de diversidad de Shannon-Wiener para cada parche y se aplicaron análisis multivariados (análisis de correspondencia detendenciado -DCA- e índice de indicador de especies) para estudiar la composición de la comunidad. En el DCA se asoció la muestra de parche con su exposición. Se relacionaron cuatro variables cuantitativas (tamaño del parche, cobertura relativa de familias, Physciaceae, Parmeliaceae y Collemataceae, que fueron las más representativas) con los primeros dos ejes del DCA, usando coeficiente de correlación. Se identificaron 21 especies en los parches. El análisis multivariado de las unidades muestrales evidenció preferencia de algunas especies a la exposición de los parches al cultivo. Los datos muestran una degradación debida al impacto del borde en el bosque remanente. Existe una tendencia hacia las comunidades más homogéneas, formadas por especies resistentes a estas condiciones de borde y que presentan altos valores de cobertura.

Palabras clave: agricultura, Chaco, epifitas, estructura de la comunidad.

\section{INTRODUCTION}

The conservation of native forests is an essential component for the maintenance of the biodiversity that they sustain. In the Chaco region, large forest areas are affected by different factors, especially the deforestation for lumber use or the advance of the agricultural border that, lately, has led to the fragmentation of formerly contiguous forests (Hoyos et al. 2012). Forest fragmentation represents one of the major threats to global biodiversity conservation (Hedenås and Ericson 2000).

When continuous cover of forests becomes disperse patches with different sizes and isolation, the ecological process changes (Rheault et al. 2003). Fragmentation produced changes in clime homeostasis and in biotic-abiotic conditions. As a general rule, in the edge of patches, clime conditions (humidity, temperature and light) became extreme and not adequate for living organisms adapted to living in the center of the forest (Renhorn et al. 1997, Rehault et al. 2003). These conditions generate changes in the responses of forest lichen communities.

Lichen communities play an important role in the forest ecosystem, although they are not the major part of the biomass. Included in these roles are: nitrogen fixation, the cycle of nutrients and the provision of materials for feeding or nests construction (Will-Wolf et al. 2002). 
Epiphytic lichens are dependent on the substrate they grow up (Snäll et al. 2003, 2005). They are especially sensitive to environmental variations because they have no regulation mechanisms to acquire or lose water and take their nutrient from atmospheric sources. By the above, epiphytic lichens are sensitive to fragmentation and forest management (Kivistö and Kuusinen 2000, Aragón et al. 2010). Such alterations reduce substrate availability (such as tree bark) and produce changes in micro clime conditions (Hilmo and Såstad 2001), generating lichens variations in composition and diversity (Johansson 2008). Lichens are also an important component of biodiversity and habitat for numerous living organisms such as insects, mollusks, mitts and amphibians (Esseen and Renhorn 1998).

In central Argentina and particularly in Chaco region, studies have been carried out to know lichen diversity in different environments (Estrabou et al. 2005, Estrabou et al. 2006) and to evaluate modifications against disturbances (Estrabou et al. 2004, 2011, Quiroga et al. 2008, Rodriguez et al. 2009). No study has been carried out to know changes in lichens community in fragmented forests. We assume that lichen diversity diminishes in patches and increases the cover of species that tolerate or resist the new conditions.

The present work aims at knowing and evaluating changes in the structure of epiphytic lichen communities (cover, richness, diversity and composition) in remnant forest in Chaco region.

\section{METHODS}

Study area. The study area is located in the phytogeographic Province of Chaco (Cabrera 1976) belongs to the ecoregion of the Gran Chaco (Morello 1983). This area is characterized by a strong seasonality and a large daily temperature range. It presents a heterogeneous matrix with forest patches with different sizes and different degrees of disturbance. The vegetation of the Chaco forest zones with little disturbance is characterized by the presence of trees as Aspidosperma quebracho-blanco Schltdl., Prosopis alba Griseb., Prosopis nigra Griseb. and Zizyphus mistol Griseb. Some patches are in contact with crops in only one of its edges, while others are totally enclosed within them becoming true "islands" (isolated patches) of native forest. Due to this management, on these patches of forest, some tree species are lost and replaced by other species such as Acacia caven (Molina) Molina, Acacia praecox Griseb., among others, thus bushes receive more sunlight. In addition, they are more exposed to particulate products of land-work and spraying, among other factors affecting them (Viglizzo et al. 2010). In addition, the isolated patches are exposed to products used in the agriculture.

Sampling. Inside the "Chaco Oriental” (Luti et al. 1979), 15 patches of native forest bordering farmland were sampled for this study, which was carried out between 2010 and 2011. These patches are irregularly distributed in a homogeneous area of $50 \mathrm{~km}^{2}$ ( $30^{\circ} 31^{\prime} \mathrm{S}$ and $30^{\circ} 53^{\prime} \mathrm{S} 63^{\circ} 69^{\prime}$ $\mathrm{W}$ and $64^{\circ} 09^{\prime} \mathrm{W}, 450 \mathrm{~m}$ a.s.l.) (figure 1). Each patch was geopositioned and data on its size and exposure to the crop were recorded. The patches were mostly rectangular and the exposure was specified according to number of sides of the patch bordering the crops. The patches were classified into three types: isolated patches (forest in the middle of crops), two borders (patches with two borders to the crops), one border (patches with one border to the crops) (table 1). Roads, shrublands or grasslands limited the patches with borders without crops. In each patch 10 phorophytes belonging to the native flora of the place, with diameter at breast height over $10 \mathrm{~cm}$, were randomly selected. A total of 150 phorophytes were sampled. The coverage for each species of lichen present on the southwest side of trees - the side of the trunk which has higher coverage of lichens in this region- and at $1.50 \mathrm{~m}$ in height was determined for each phorophyte using a transparent plastic grid of $20 \times 20 \mathrm{~cm}$. This method was standardized in Estrabou and García (1995), Estrabou (2007) and Estrabou et al. (2011).

All species were identified using routine methods (Estrabou et al. 2006); with the exception of crustose lichens which were identified at genus level or not classified. For each species, the family and percentage of coverage were determined.

Data analysis. A Kruskal Wallis test was applied for the total lichen cover in order to know if there are significant differences among the patches. Moreover, Spearman correlation index was applied for the total lichen cover and richness.

For each patch studied, the species richness was registered and diversity index of Shannon-Wiener (H') was calculated according to the formula [1].

$\mathrm{H}^{\prime}=-\Sigma \mathrm{pi}^{*} \log (\mathrm{pi})$

where

$\mathrm{pi}=$ relative proportion (coverage) of the i species.

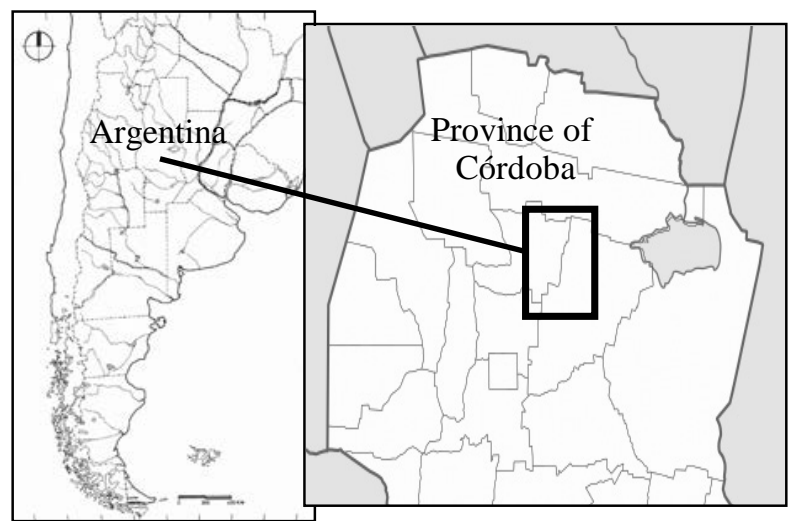

Figure 1. Location of the study area. Ubicación del sitio de estudio. 
Table 1. Size and exposition to culture of the 15 sampled patches. de bosque.

Tamaño y exposición a cultivo de quince muestras de parches

\begin{tabular}{ccc}
\hline Patches & Size (ha) & Patch exposition to culture \\
\hline 1 & 0.90 & isolated patches \\
2 & 0.30 & 2 borders \\
3 & 0.51 & 1 border \\
4 & 0.66 & isolated patches \\
5 & 3.40 & isolated patches \\
6 & 1.04 & 2 borders \\
7 & 0.82 & 2 borders \\
8 & 0.57 & isolated patches \\
9 & 0.22 & isolated patches \\
10 & 0.10 & 1 border \\
11 & 0.10 & 1 border \\
12 & 1.35 & 1 border \\
13 & 0.15 & 2 borders \\
14 & 50.00 & 2 borders \\
15 & 52.00 & 2 borders \\
\hline
\end{tabular}

The composition of the community was studied calculating the relative cover of lichen families. Also a detrended correspondence analysis ordination (DCA) was conducted on a matrix of sample units by species cover to detect groups. We calculated coefficients of determination between original sample unit's distances and distances in the final ordination solution to assess how much variability in lichen community composition was represented by the DCA axes (McCune and Grace 2002). The sample points in the DCA were associated with the qualitative variable patch exposition using different symbols for each group. Also, four quantitative variables were related with the first two axes of DCA using correlations coefficients (McCune and Grace 2002). The variables used were: patch size, relative cover of Physciaceae, Parmeliaceae and Collemataceae families.

In addition, Indicator Species Analysis (Dufrene and Legendre 1997) was applied using a Monte-Carlo simulation to detect species that have significant preferences for exposure to culture (McCune and Grace 2002). In order to filter noise that could underlie the structure of the data and to reduce the stochastic effects of rare species, we applied the multivariate analysis to a partial dataset including only the lichen species found in more than 15 trees (more than $10 \%$ frequency). The data analysis was performed using Infostat v. 2011 and PCORD v. 5.1.

\section{RESULTS}

Figure 2 shows the diversity index and the average of total lichen cover for each patch. Only four species were identified in patch 8,9 and 11 . On the other hand, 14 spe-
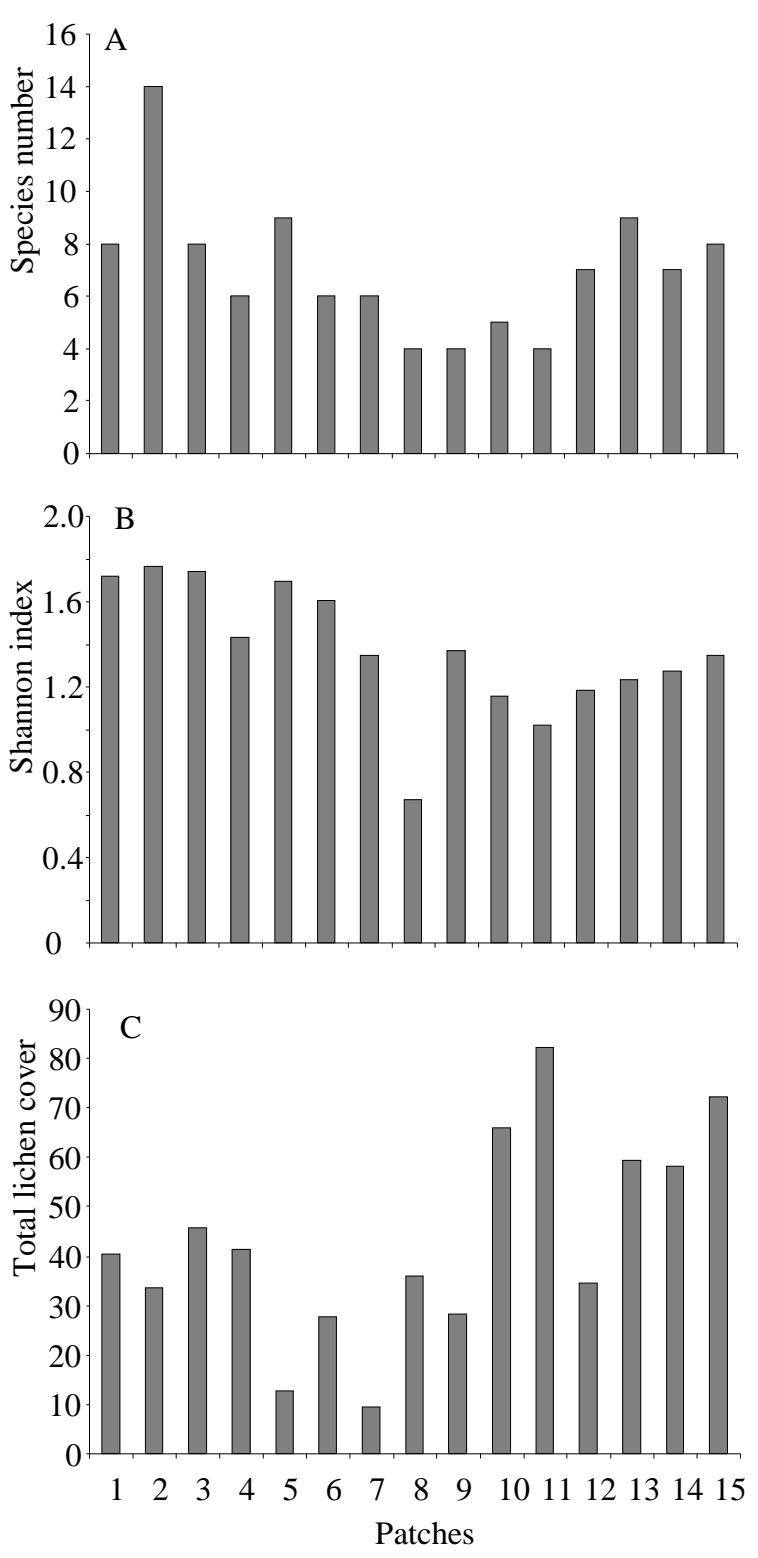

Figure 2. A: Richness, B: Shannon-Wiener index and C: average cover or total cover in patches.

A: Riqueza, B: Índice de Shannon-Wiener y C: Porcentaje de cobertura total en los parches.

cies were identified in patch 2 . The highest diversity was found in patch number 2 and the smallest one was found in patch number 8. Average of the total lichen coverage and diversity did not show relation (Spearman correlation index was 0.35 ). The highest cover was registered for patch 11 with only four species (Physcia undulata, Candelaria concolor, Canoparmelia crozalsiana and Punctelia microsticta). On the other hand, patches seven and five contain six and nine species respectively with poor lichen cover. In general, the total lichen cover showed significant differences among patches (Kruskal-Wallis test with $P<0.0001$ ). 
The composition of the lichen community in forest patches was represented by twenty one species (table 2). The $38.10 \%$ of the species belongs to the family Physciaceae, the $38.10 \%$ to the Parmeliaceae and $9.52 \%$ to the Collemataceae; they represent almost the $90 \%$ of the lichen cover. Families Telochistaceae, Candelariaceae and Ramalinaceae were represented by $4.76 \%$.

The first three ordination axis of DCA analysis captured $47.1 \%$ of the variability in the dataset (figure 3). The ordination analysis showed three groups of samples partially related with the exposition of patches to crops. Group A is partially composed by samples from patches with two borders to crops and associated with Parmotrema pilosum, P. reticulatum, Punctelia microsticta and Hyperphyscia endochryscea. Group B is composed by samples from patches with one border to crops and associated with Ramalina celastri, Leptogium cyanescens, Collema sp. and Physcia erumpens. Group $\mathrm{C}$ is not clearly defined but it is composed mainly by samples from patches in isolated patches and associated with Physcia undulata and Heterodermia albicans.
The size of patches did not show correlation with the axis (Axis $1 \mathrm{r}=-0.086$, Axis $2 \mathrm{r}=0.028$ ). The cover of Physciaceae family correlated weakly with axis $1(\mathrm{r}=$ 0.261 ). The cover of Parmeliaceae family correlated negatively with axis $1(\mathrm{r}=-0.361)$. The cover of Collemataceae family correlated positively with axis $1(\mathrm{r}=0.644)$.

The species indicator analysis for the patch exposition showed (table 3) that Candelaria concolor had preference for the patches in isolated patches. The species Physcia aipolia, $P$. erumpens, Ramalina celastri, Collema sp. and Leptogium cyanescens were indicator of patches with one border to crops. Finally, Hyperphyscia endochryscea, Parmotrema pilosum and P. reticulatum were indicators of patches with two borders to crops.

\section{DISCUSSION AND CONCLUSIONS}

The total lichen coverage in patches was $34.09 \%$ in average. This value is relatively high when compared to studies carried out in the region (Estrabou et al. 2005, Estrabou 2007). However, when the patches species were

Table 2. Lichen species found in all sampled patches, family and average cover of each one. Especies liquénicas encontradas en los parches, familias y porcentaje de cobertura de cada una.

\begin{tabular}{|c|c|c|}
\hline Species & Average cover & Family \\
\hline Candelaria concolor (Dickson) Arnold. & 0.57 & Candelariaceae \\
\hline Collema sp. & 7.17 & Collemataceae \\
\hline Leptogium cyanescens (Ach.) Körb & 3.22 & Collemataceae \\
\hline Canoparmelia crozalsiana (de Lesd.) Elix et Hale* & 0.49 & Parmeliaceae \\
\hline Canoparmelia texana (Tuck.) Elix et Hale* & 0.03 & Parmeliaceae \\
\hline Parmotrema austrosinense (Zahlbr.) Hale* & 1.00 & Parmeliaceae \\
\hline Parmotrema cetratum (Ach.) Blanco et al.* & 0.20 & Parmeliaceae \\
\hline Parmotrema conferendum (Hale) Kurok.* & 0.03 & Parmeliaceae \\
\hline Parmotrema pilosum (Stizenb.) Elix et Hale & 9.46 & Parmeliaceae \\
\hline Parmotrema reticulatum (Taylor) Hale et A. Fletcher & 1.79 & Parmeliaceae \\
\hline Punctelia microsticta (Müll. Arg.) Krog & 1.65 & Parmeliaceae \\
\hline Heterodermia albicans (Pers.) Swinscow et Krog & 1.57 & Physciaceae \\
\hline Hyperphyscia endochryscea (Kremp.) Moberg & 1.42 & Physciaceae \\
\hline Physcia aipolia (Humb.) Fürnrohr. & 1.59 & Physciaceae \\
\hline Physcia alba (Fee) Müll. Arg* & 0.04 & Physciaceae \\
\hline Physcia erumpens Moberg & 2.80 & Physciaceae \\
\hline Physcia poncisnii Hue.* & 1.81 & Physciaceae \\
\hline Physcia tribacia (Ach.) Nyl.* & 0.28 & Physciaceae \\
\hline Physcia undulata Moberg & 6.30 & Physciaceae \\
\hline Ramalina celastri (Spreng.) Krog et Swinscow & 1.31 & Ramalinaceae \\
\hline Teloschistes cymbalifer (Meyer) Müll. Arg.* & 0.01 & Telochistaceae \\
\hline Crustose & 0.43 & \\
\hline
\end{tabular}

* Species excluded from multivariate analysis (less than $10 \%$ frequency). 


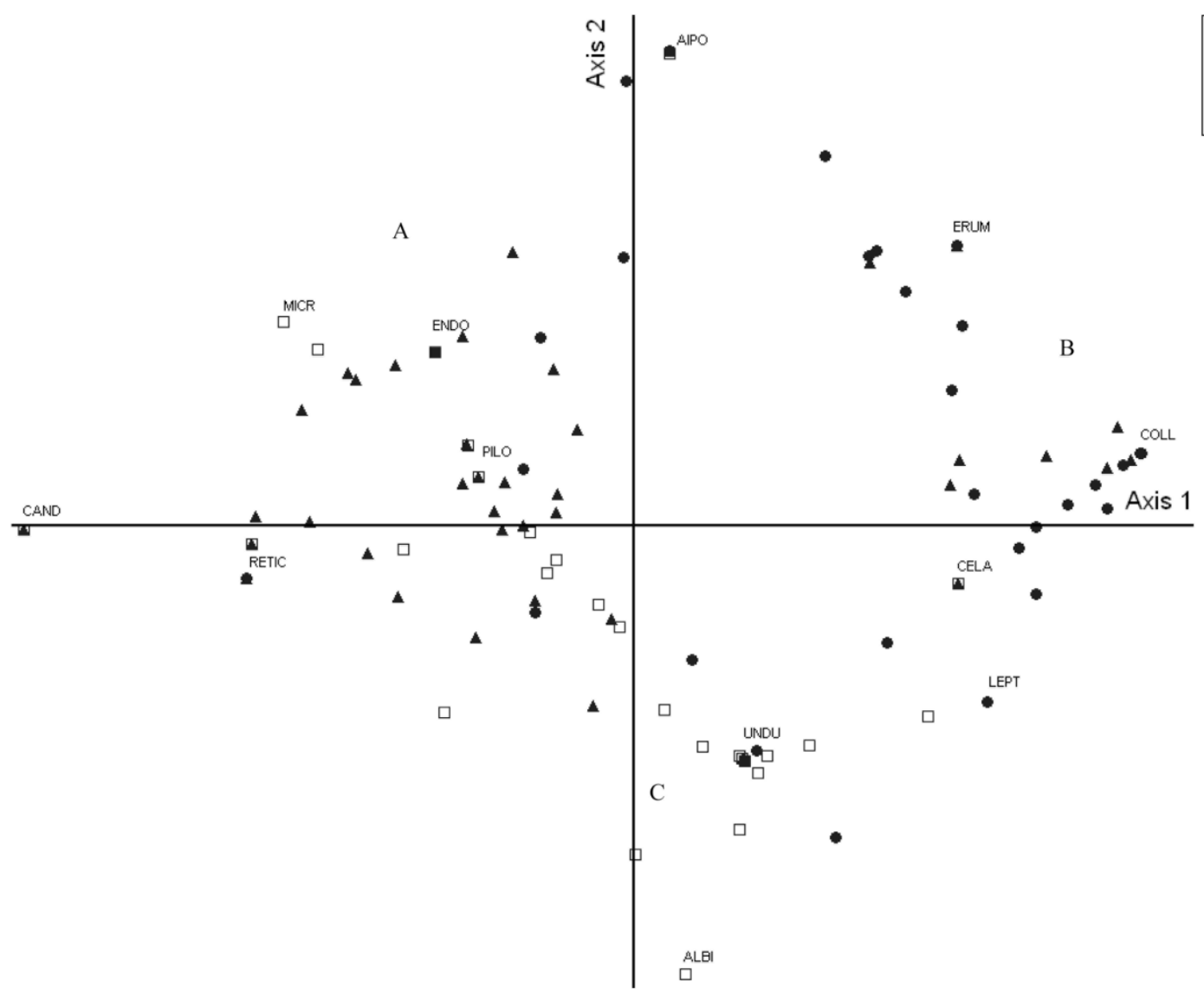

Figure 3. Detrended correspondence analysis (DCA) of samples. Samples are differentiated according to the exposition to crops. Letters A, B and C indicate grouping (see in the text). Species: CAND = Candelaria concolor, $\mathrm{PILO}=$ Parmotrema pilosum, $\mathrm{ALBI}=$ Heterodermia albincans, ENDO = Hyperphyscia endochryscea, LEPT = Leptogium cyanescens, RETIC = Parmotrema reticulatum, AIPO = Physcia aipolia, ERUM = Physcia erumpens, UNDU $=$ Physcia undulata, MICR $=$ Punctelia microsticta, CELA $=$ Ramalina celastri, COLL = Collema sp.

Análisis de correspondencia detendenciado (ACD) de las muestras. Las muestras se diferencian de acuerdo con la exposición al cultivo. Letras A, B y C indican agrupaciones (ver en el texto). Especies = CAND: Candelaria concolor, PILO: Parmotrema pilosum, ALBI: Heterodermia albincans, ENDO: Hyperphyscia endochryscea, LEPT: Leptogium cyanescens, RETIC: Parmotrema reticulatum, AIPO: Physcia aipolia, ERUM: Physcia erumpens, UNDU: Physcia undulata, MICR: Punctelia microsticta, CELA: Ramalina celastri, COLL: Collema sp.

Table 3. Indicator species analysis for the patches exposition. Only species with $P<0.05$ in the Monte Carlo test are shown. Análisis de indicador de especie para la exposición de los parches. Sólo se muestran especies con $P<0,05$ en la prueba de Monte Carlo.

\begin{tabular}{|c|c|c|c|c|c|}
\hline Species with $P<0.05$ & $\begin{array}{c}\text { Category of } \\
\text { exposition }\end{array}$ & $\begin{array}{c}\text { Observed } \\
\text { indicator value }\end{array}$ & $\begin{array}{c}\text { Expected } \\
\text { indicator value }\end{array}$ & $\begin{array}{l}\text { Standard } \\
\text { deviation }\end{array}$ & $P$ \\
\hline Candelaria concolor & Isolated & 20.1 & 7.8 & 2.57 & 0.0020 \\
\hline Leptogium cyanescens & 1 border & 28.4 & 9.3 & 2.85 & 0.0002 \\
\hline Physcia aipolia & 1 border & 18.2 & 8.8 & 3.05 & 0.0116 \\
\hline Physcia erumpens & 1 border & 15.5 & 7.2 & 2.53 & 0.0096 \\
\hline Ramalina celastri & 1 border & 13.6 & 7.8 & 2.83 & 0.0450 \\
\hline Collema sp. & 1 borders & 18.4 & 7.3 & 2.30 & 0.0016 \\
\hline Parmotrema pilosum & 2 borders & 31.6 & 17.0 & 3.36 & 0.0018 \\
\hline Hyperphyscia endochryscea & 2 borders & 22.4 & 9.5 & 2.81 & 0.0008 \\
\hline Parmotrema reticulatum & 2 borders & 17.6 & 7.8 & 2.59 & 0.0048 \\
\hline
\end{tabular}


studied, this coverage was dominated by few species tolerant to environmental conditions of the patches. These results show that the coverage of lichens -without discrimination of species- has little importance in the assessment of disturbed ecosystems. Similar observations have been noted by Rosentreter and Eldridge (2002).

The dominant species in the patches are Physcia undulata and Parmotrema pilosum, with high levels of coverage. The other characteristic species of the contiguous forest studied by Estrabou (2007) are in a very low coverage in the patches, except for $P$. pilosum.

Particularly, $R$. celastri has a minimum coverage in tree trunks but a superior coverage in branches (unpublished data). Stoffer et al. (2006) found the decline of fruticose species in farmland environments. However more data are needed to evaluate the performance of these species as sensitive in these environments, especially considering branches or shrubs.

The exposure of the patch to the crops explains partially the differences found among patches. Patches with one border exposed have a community whose best indicator species are cyanolichens (Collema sp., Leptogium cyanescens), fruticose (Ramalina celastri) or less frequent species (Physcia erumpens, P. aipolia). The indicator species of patches with two borders exposed to crops (Parmotrema pilosum, P. reticulatum and Hyperphyscia endochryscea.) have been described as indicators of deterioration processes in Chaco forests (Quiroga et al. 2008, Rodriguez et al. 2009). Finally, Candelaria concolor is a strong indicator of the patches on isolated patches. It is a micro-foliose species, resistant to high radiation and tolerant to contaminated sites (Estrabou et al. 2005, 2011).

While Physcia undulata does not appear to display significant values in the Indicator Analysis, the DCA makes a closer relationship with isolated patches. This species is present in good coverage in almost all patches not being associated with any particular feature. This species, together with Candelaria concolor, would indicate the highest degree of deterioration as in other studies in the region (Estrabou et al. 2005, 2011).

According to Van Haluwyn and Van Herk (2002) the macro-environmental change in the characteristics resulting from the agricultural land use may not affect the species that require light, but it could cause loss of lichens species typical of the Chaco forest. The results indicate that there would be a degradation gradient marked by the impact of the edges on the remaining forests. There is a trend towards more homogeneous communities, formed by species resistant to these boundary conditions and with high coverage. In general the community in patches was composed by foliose species such as Parmotrema pilosum, Physcia undulata, Hyperphyscia endochryscea and Candelaria concolor. The community in these areas under agricultural use is similar to the one studied in urban environments with the same dominants: Physcia undulata and Hyperphyscia endochryscea, which was described as resistant to pollution (Estrabou 1998).
Based on the obtained results we suggest that the main response to forest patches conditions is that the diversity of the lichen community decreases. Secondary there is a replacement of some lichen species belonging to the original forest environments and finally there is an increase in the cover of few species mostly tolerant or resistant to the new conditions.

\section{REFERENCES}

Aragón G, I Martínez, P Izquierdo, R Belinchón, A Escudero. 2010. Effects of forest management on epiphytic lichen diversity in Mediterranean forests. Applied Vegetation Science 13:183-194.

Cabrera A L. 1976. Regiones fitogeográficas argentinas. In Kugler WF ed. Enciclopedia Argentina de Agricultura y Jardinería. Buenos Aires, Argentina. p. 1-85.

Dufrene M, P Legendre. 1997. Species assemblages and indicator species: the need for a flexible asymmetrical approach. Ecological Monographs 67:345-366.

Esseen PA, KE Renhorn. 1998. Edge effects on an epiphytic lichen in fragmented forests. Conservation Biology 12:13071317.

Estrabou C, L García. 1995. Comunidades liquénicas cortícolas sobre Lithraea ternifolia en las Sierras Chicas de la provincia de Córdoba, Argentina. Botanica Complutensis 20: 35-43.

Estrabou C. 1998. Lichen species identification and distribution according tolerance to airborne contamination in the city of Córdoba, Argentina. In Marcelli MP, MRD Seaward eds. Lichenology in Latin America: History, Current Knowledge and Applications. CETESB, São Paulo. p. 165-169.

Estrabou C, L Stiefkens, M Hadid, JM Rodríguez, A Pérez. 2004. Efectos de contaminación del aire sobre la morfología y reproducción en cuatro especies de líquenes. Ecología en Bolivia 39(2): 33-45.

Estrabou C, L Stiefkens, M Hadid, JM Rodríguez, A Pérez. 2005. Estudio de la comunidad liquénica en cuatro ecosistemas de la provincia de Córdoba. Boletín de la Sociedad Argentina de Botánica 40(1-2):3-12.

Estrabou C, JM Rodríguez, B Priori, R Lijteroff. 2006. Contribución al conocimiento de los macrolíquenes del extremo Sur del Gran Chaco (Argentina). Kurtziana 32(1-2):25-43.

Estrabou C. 2007. Preferencia de forófito por los líquenes en el bosque chaqueño oriental. Bosque 28(1):46-49.

Estrabou C, E Filipini, JP Soria, G Schelotto, JM Rodriguez. 2011. Air quality monitoring system using lichens as bioindicators in central Argentina. Environmental Monitoring and Assessment 182(1):375-383.

Hedenås H, L Ericson. 2000. Epiphytic macrolichens as conservation indicators: successional sequence in Populus tremula stands. Biological Conservation 93:43-53.

Hilmo O, SM Såstad. 2001. Colonization of old-forest lichens in a young and an old boreal Picea abies forest: an experimental approach. Biological Conservation 102:251-259.

Hoyos L, A Cingolani, M Zak, MV Vaieretti, D Gorla, M Cabido. 2012. Deforestation and precipitation patterns in the arid Chaco forests of central Argentina. Applied Vegetation Science 16(2):260-271.

Johansson P. 2008. Consequences of disturbance on epiphytic 
lichens in boreal and near boreal forests. Biological Conservation 141:1933-1944.

Kivistö L, M Kuusinen. 2000. Edge effects on the epiphytic lichen flora of Picea abies in middle boreal Finland. The Lichenologist 32:387-398.

Luti R, A Solis, FM Galera, M Berzal, M Nores, M Herrera, J Barrera. 1979. Vegetación. In Vázquez JB, R Miatello, M Roqué eds. Geografía física de la provincia de Córdoba. Buenos Aires, Argentina. Editorial Bolt. p. 297-367.

McCune B, J Grace. 2002. Analysis of ecological communities. MjM Software Design. Gleneden Beach , Oregon.

Morello J. 1983. El Gran Chaco: El proceso de expansión de la frontera agrícola desde el punto de vista ecológico ambiental. In CEPAL-PNUMA eds. Expansión de la frontera agropecuaria y medio ambiente de América Latina. Madrid, España. p.343-395.

Quiroga G, C Estrabou, JM Rodriguez. 2008. Lichen community response to different management situations in a protected forest of Córdoba, Argentina. Lazaroa 29:131-138.

Renhorn KE, PA Esseen, K Palmqvist, B Sundberg. 1997. Growth and vitality of epiphytic lichens. I. Responses to microclimate along a forest edge-interior gradient. Oecologia 109(1):1-9.

Rheault H, P Drapeau, Y Bergeron, PA Esseen. 2003. Edge effects on epiphytic lichen in managed black spruce forest of eastern North America. Canadian Journal of Forest Research 33:23-32.

Rodriguez JM, C Estrabou, R Fenoglio, F Robiati, C Salas, G Quiroga. 2009. Recuperación post-fuego de la comunidad de líquenes epifitos en la provincia de Córdoba, Argentina. Acta Botánica Brasílica 23(3):854-859.
Rosentreter R, DJ Eldrige. 2002. Monitoring biodiversity and ecosystem function: grassland, deserts and steppe. In Nimis PL, C Scheidegger, PA Wolseley eds. Monitoring With Lichens-Monitoring Lichens. NATO Science Series. Dordrecht, Netherlands. Kluwer Academic Publishers. p. 223-238.

Snäll T, J Ehrlén, H Rydin. 2005. Colonization-extinction dynamics of an epiphyte metapopulation in a dynamic landscape. Ecology 86:106-115.

Snäll T, PJ Ribeiro, H Rydin. 2003. Spatial occurrence and colonisations in patch-tracking metapopulations: local conditions versus dispersal. Oikos 103:566-578.

Stofer S, A Bergamini, G Aragón, P Carvalho, BJ Coppins, S Davey, M Dietrich, E Farkas, K Karkkainen, C Keller, L Lökös, S Lommi, C Máguas, R Mitchell, P Pinho, VJ Rico, AM Truscott, PA Wolseley, A Watt, C Scheidegger. 2006. Species richness of lichen functional groups in relation to land use intensity. The Lichenologist 38(4):331-353.

Van Haluwyn C, CM Van Herk. 2002. Bioindication: The community approach. In Nimis PL, C Scheidegger, PA Wolseley eds. Monitoring With Lichens-Monitoring Lichens. NATO Science Series. Dordrecht, Netherlands. Kluwer Academic Publishers. p. 39-64.

Viglizzo EF, FC Frank, LV Carreño, EG Jobbágy, H Pereyra, J Clatt, D Pincén, MF Ricard. 2010. Ecological and environmental footprint of 50 years of agricultural expansion in Argentina. Global Change Biology 17(2):959-973

Will-Wolf S, PA Esseen, P Neitlich. 2002. Monitoring Biodiversity and Ecosystem Function: Forests. In Nimis PL, C Scheidegger, PA Wolseley eds. Monitoring with lichens monitoring lichens. Dordrecht, Netherlands. Kluwer Academic Publishers. p. 203-222. 
